\title{
JOHN ADAMS AND THE POLITICS OF DISJUNCTION
}

\author{
MARCIN GAJEK
}

\begin{abstract}
While John Adams' position as one of the prominent founding fathers has never been disputed, his presidency is predominantly assessed as mediocre. Many scholars argued that Adams was not only deprived of leadership and executive skills, but that he also lacked a coherent policy vision. The present paper argues that Adams' failure as a chief-executive resulted not from the lack of a set agenda but rather from his outdated visions of politics and presidency. Both his leadership style and specific policies pursued by him constitute an example of the politics of disjunction. His desire to follow Washington's Farewell Address was doomed to failure because of the quick transformation of American politics at the beginning of the nineteenth century. At the same time, his attachment to the classical ideal of the "aristocratic republic" was indefensible in the era of progressing democratization of popular moods. Combined, those two elements resulted in Adams failing to provide strong leadership to the Federalist party and to his inability to secure presidential re-election.
\end{abstract}

Keywords: United States, John Adams, presidency, politics of disjunction

DOI: $10.14712 / 23363231.2016 .2$

\section{Introduction}

The second president of the United States did not enjoy great popularity among his contemporaries. "Some presidents leave the executive office in fame and glory," wrote his biographer, "others in shame and disgrace. Adams left in

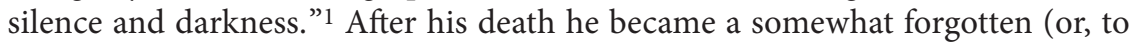
use a gentler expression, effaced) person. He himself predicted his posthumous obscurity. "Mausoleums, statues, monuments will never be erected to me [...].

1 John Patrick Diggins, John Adams (New York: Times Books, 2003), 2. Also see George W. Carey, Introduction to The Political Writings of John Adams, ed. George W. Carey (Washington, DC: Regnery Publishing, 2000), vii; and Gilbert Chinard, Honest John Adams (Boston: Little, Brown, 1964), v. 
Panegyrical romances will never be written, nor flattering orations spoken, to transmit me to posterity in brilliant colors." 2 The foregoing words proved to be prophetic. Contemporary Americans feel a common admiration for George Washington, Benjamin Franklin or Thomas Jefferson. Their stars shine most brightly. Their names are recalled in almost every discussion concerning the founding era. The authors of The Federalist Papers, especially Madison and Hamilton, are also quoted much more often in studies devoted to the beginnings of the American republic. ${ }^{3}$ Even in his native state, Massachusetts, the second president of the United States loses the battle for civic memory with his cousin Samuel Adams. Indeed, John Adams was by no means a popular statesman.

The uncompromising character of his philosophical and political views, combined with an impolitic behavior and the lack of personal charm, won him enemies rather than friends. He had rather impetuous personality and, at times, emotions took over his reason (as he himself admitted), which discouraged people from him. ${ }^{4} \mathrm{He}$ also had an unfortunate habit of being sincere and straightforward; he used to speak and write openly what he had in mind - without paying much attention to the possible misperceptions of his views. He was always ready to enter into a polemic and - as he put it himself - "quarrel with both parties and every individual in each." 5 Without a doubt, he was not a master in the art of creating a positive self-image. Actually, he "scorned self-promotion" and cared very little for popularity ${ }^{6}$ and this despite the fact that his diaries reveal a serious

2 John Adams, "To Benjamin Rush, 23 March 1809," in The Works of John Adams, ed. Charles Francis Adams, vol. 9 (Boston: Little, Brown and Co., 1856).

3 All this despite the fact that many scholars stressed the great influence of Adams' political writings especially A Defence of the Constitutions of the Government of the United States of America - on the Framers deliberating at the Great Convention in Philadelphia in 1787. See Manning Julian Dauer, The Adams Federalists (Baltimore, MD: Johns Hopkins University Press, 1968), 50-51. According to Richard Hofstadter, the third volume of A Defence was quoted with a common approval during the Convention by several delegates. See Richard Hofstadter, The American Political Tradition and the Men Who Made It (New York, NY: Vintage Books, 1961), 10. Furthermore, Adams' earlier work Thoughts on Government as well as Massachusetts constitution drafted by him strongly influenced the authors of states' constitutions. See John R. Howe, The Changing Political Thought of John Adams (Princeton, NJ: Princeton University Press, 1966), 80-81; and David Waldstreicher, "Introduction: The Adams Paradox," in A Companion to John Adams and John Quincy Adams, ed. David Waldstreicher, WileyBlackwell Companions to American History (Malden, MA: Wiley-Blackwell, 2013), 12.

4 See for example Fred I. Greenstein, "Presidential Difference in the Early Republic: The Highly Disparate Leadership Styles of Washington, Adams, and Jefferson," Presidential Studies Quarterly 36, no. 3 (September 1, 2006): 384.

5 Quoted in Fred I. Greenstein, Inventing the Job of President: Leadership Style from George Washington to Andrew Jackson (Princeton, NJ: Princeton University Press, 2009), 32.

6 Greenstein, "Presidential Difference," 385; and Andy Trees, "John Adams and the Problem of Virtue," Journal of the Early Republic 21, no. 3 (2001): 397-98. 
preoccupation with how he will be remembered). For honesty and going against the common opinion he paid with personal unpopularity and the defeat in the 1800 presidential elections.

Against this background it is noteworthy that at the beginning of the twenty-first century we witnessed a renaissance of interest in John Adams. One of his latest biographies had been awarded a Pulitzer Prize ${ }^{7}$ and became a basis for an HBO television mini-series which won an Emmy Award. ${ }^{8}$ Also several new important scholarly studies devoted to Adams have been published, ${ }^{9}$ which create an opportunity for a renewed reflection on the reasons of his political failure.

According to Fred Greenstein the second president of the United States "had no general policy vision," which combined with his lack of political skill resulted in the poor presidency. ${ }^{10}$ While Adams' shortcomings in regards to specific executive skills as well as personal charm are commonly known (and well documented), I argue that the predominant reasons of his political failure as the president resulted not from the lack of policy vision or a set agenda. Rather the vision advocated by Adams was inadequate to his times. Adopting Stephen Skowronek's typology, introduced in The Politics Presidents Make, I argue that John Adams was a leader pursuing the politics of disjunction - that is, sustaining the regime and defending views which no longer enjoyed public support. His political activity - both as vice-president and as president - reveals a serious incompatibility with his times and with popular moods prevailing among his fellow citizens. In the light of such analysis, John Adams can be presented simply as the leader who - despite his great intellectual perspicacity ${ }^{11}$ was a poor reader of his own times.

As Stephen Skowronek notes, leaders who have pursued the politics of disjunction were usually unsuccessful. The second president of the United States was no exception. The balance of his presidency confirms this assumption: not only did he lose re-elections to Thomas Jefferson in 1800; his actions also caused the

${ }^{7}$ David G. McCullough, John Adams (New York, NY: Simon and Schuster, 2001).

8 John Adams, TV mini-series, directed by Tom Hooper (2008; New York, HBO Video).

9 Waldstreicher, A Companion to John Adams; Greenstein, Inventing the Job; Greenstein, "Presidential Difference"; and Trees, "John Adams and the Problem of Virtue."

10 Greenstein, "Presidential Difference," 386-87.

${ }^{11}$ Vernon Louis Parrington, for example, in his monumental history of American thought describes Adams as "the most notable political thinker - with the possible exception of John C. Calhoun among American statesmen." See Vernon Louis Parrington, Main Currents in American Thought, Volume 1: The Colonial Mind, 1620-1800 (Norman, OK, and London: University of Oklahoma Press, 1987), 320. For more examples of the appreciation of Adams political thought see Stephen G. Kurtz, "The Political Science of John Adams: A Guide to His Statecraft," The William and Mary Quarterly 25, no. 4 (1968): 607-8. 
breakup of his own political camp. ${ }^{12}$ In the present essay I will try to demonstrate why Adams' policy led to the above-mentioned defeat, but also in what ways his political philosophy was less and less compatible with prevailing moods (both of ordinary citizens and of political elites). It is important to remember that Adams was primarily a theoretician of politics, and only secondarily a practicing politician. His theoretical studies of politics greatly influenced both the style of his presidency and his political decisions. However, as the present essay is a study in political leadership rather than in political philosophy, I will analyze only selected and most relevant themes of Adams' political doctrine.

\section{The Presidency of John Adams and Its Political Context}

Before I examine in detail specific policies advocated by the second president of the United States, which constituted the politics of disjunction, some preliminary remarks concerning Adams' situation and position on the American political scene seem necessary. His predecessor in the presidential office was, one could say, the "natural first president" of the American republic. Washington's presidency was commonly perceived as the only possible aftermath of adopting the Constitution. The first elections in 1789 were simply a formal confirmation of the obvious. The thirteen former English colonies in America, shortly after the commonly undertaken war effort resulting in their independence, were still very much distinct, sovereign entities. It is a common oversimplification of textbooks to point at the Civil War as the great illustration of separate, and sometimes contradictory, interests of different states. In fact, those differences had their roots in colonial times and were already clearly visible in the founding era. Mutual distrust between the northern and southern states, strengthened by the awareness of different economic interests and social institutions, expressed itself vigorously during the process of ratifying the Constitution. Both sides were afraid that the federal government, established by the new fundamental law, might be used to promote the interests of one of these regions with simultaneous neglect of the other. ${ }^{13}$ The only factor capable of linking together those different states and instilling a sense of fellowship was the

12 However, it is an open question who contributed more to both failures: president Adams or the actual (though informal) leader of the Federalists, Alexander Hamilton? The fact is that the 1800 elections mark the beginning of the decomposition of the Federalists, who never again managed to elect their own president and by 1820 practically ceased to exist. For a comprehensive discussion of Adams' presidency see Ralph Adams Brown, The Presidency of John Adams (Lawrence, KS: University Press of Kansas, 1989).

${ }^{13}$ Melvin E. Bradford, Original Intentions: On the Making and Ratification of the United States Constitution (Athens, GA: University of Georgia Press, 1993), 49-50, 63-66, 80. 
fresh memory of a common enemy and of the commonly fought (and won) war. Who else but the victorious General, who led the united army during the war, could become the first president of the young, newly founded republic? Washington's candidacy for that position was not only desirable but also widely expected.

The only question to be answered was: who should become vice-president? John Adams' candidacy, put up by Federalists, was to some extent accidental. The very rapprochement between Adams and his supporters resulted from political strategy rather than from proximity of political views. ${ }^{14}$ It is true that he was perceived as a nationalist, who wanted to tighten political bonds between the states under a relatively strong federal executive. At the same time, he rather disliked the states' rights theory. Nevertheless, on many questions concerning both domestic and foreign policy he differed substantially from Hamilton. He had always sympathized with the Jeffersonian concept of the "agrarian republic" and was rather suspicious of the Hamiltonian agenda for an energetic federal government - inducing the fast growth of industry and the financial sector. In his letter to John Taylor of Caroline he wrote:

I have never had but one opinion concerning banking [...] and that opinion has uniformly been that the banks have done more injury to the religion, morality, tranquility, prosperity, and even wealth of the nation than they can have done or ever will do good. They are like party spirit, the delusion of the many for the interest of a few. ${ }^{15}$

Views like this certainly made his candidacy acceptable for southerners. On the other hand, there were substantial philosophical differences between him and Jefferson. The peak of those differences was reached in their assessment of the French Revolution, which the Sage of Monticello admired and Adams fiercely criticized (and, it should be noted, preceded Edmund Burke by more than a year in doing so). ${ }^{16}$ Jeffersonian Republicans were dubbed "democratic" by their political opponents not without a reason (and the term was, obviously, used in the pejorative sense at the time). Adams feared democracy and judged it very harshly.

14 See Jerzy Grobis, Świat i polityka w pogląach Johna i Johna Quincy Adamsów (1755-1848) [World and politics in views of John Adams and John Quincy Adams] (Łódź: Wydawnictwo Uniwersytetu Łódzkiego, 1989), 122.

15 John Adams, “To John Taylor of Caroline, 12 March 1819," in The Works of John Adams, ed. Charles Francis Adams, Volume 10 (Boston: Little, Brown and Co., 1856), 375.

16 The fundamental difference of views on the French Revolution was - according to Adams' letter to Jefferson from 13 July 1813 - the main cause of the breakup of their political friendship. See John Adams, "Letter to Thomas Jefferson, 13 July 1813," in The Adams-Jefferson Letters: The Complete Correspondence between Thomas Jefferson and Abigail and John Adams, ed. Lester J. Cappon (Chapel Hill, NC: University of North Carolina Press, 1987), 354-56. 
While the leader of Democratic Republicans was clearly fascinated by French philosophées and their rhetoric of "equality of men," his Bostonian colleague was a realist - educated on seventeenth-century empirical British republicanism - who disliked arguments based on abstract speculations and appealing to the natural law in the sphere of politics.

As we can see, Adams' political views posited him somewhere between the two main competing political camps. He was officially supported by one of them but was not its real leader and, in many respects, held different views from politicians constituting its core (so-called High Federalists). Hamilton himself could not run for the presidency, being too radical and nationalistic for the South. Eventually, Adams became vice-President and then President. His situation, however, was extremely difficult: differing substantially from his own political camp, he could neither fully realize the Federalists' agenda nor completely reject it. Such a situation seems a perfect embodiment of what Stephan Skowronek defined as the politics of disjunction. When describing its main features, the author of The Politics Presidents Make writes about the "impossible leadership situation." The impossibility of this situation could be compared to that of a classically tragic figure: none of the available alternatives will guarantee success (or, to stick to the realm of drama, a "happy ending"). As Skowronek explains, "To affirm established commitments is to stigmatize oneself as a symptom of the nation's problems and the premier symbol of systemic political failure; to repudiate them is to become isolated from one's most natural political allies and to be rendered impotent."17 Moreover, such a situation characterizes a leader "affiliated with a set of established commitments that have in the course of events been called into question as failed or irrelevant responses to the problems of the day." 18 In many respects this was the situation of Adams' presidency. He was determined to continue the policy of George Washington but, because of changed circumstances, was unable to do so. One of his first decisions - to keep the personnel of Washington's administration - was clearly a manifestation of his desire to provide political continuity. It reaffirmed his affiliation with Hamiltonian Federalists and could be read as an announcement of the will to continue the policies of the past. ${ }^{19}$

17 Stephen Skowronek, The Politics Presidents Make: Leadership from John Adams to George Bush (Cambridge, MA: Belknap Press of Harvard University Press, 1993), 39.

18 Ibid.

19 Ibid., 66. It is also noteworthy that at least half of Adams' Inaugural Address was devoted to contemplating the past events and outlining the basic principles upon which American government has been founded. The second president of the United States did not set any specific agenda in his speech, nor he defined any goals of national policy. Instead he included into the Address a great praise of his predecessor - clearly sending a message that his own presidency would be a continuation of Washington's work rather than something radically different. See John Adams, 
However, Adams' decision to hold the presidential office without a cabinet reshuffle was more than a personnel decision. His vision of the president's role and of desirable national politics was enormously influenced by Washington's Farewell Address from September 17, 1796. At least three themes of that document became important elements of Adams' presidential agenda and need to be described in detail.

Before leaving office, the first president of the United States warned his fellow-citizens against entering into permanent foreign alliances and becoming involved in European politics. America, isolated from the old continent, should focus on self-development and realization of its own interests. The history of Europe was a history of wars and bloody conflicts. Puritan America, on the other hand, was supposed to be a "city upon a hill" and defined itself in opposition to the corrupted Old World. John Adams was determined to continue this politics of relative isolationism. The newly created young American republic should, in his opinion, acquire a certain level of stability and development in isolation and without foreign interference.

However, times were changing quickly and the Hamiltonian vision of America required acquisition of new lands and the capture of strategic bridgeheads. According to the Federalists the United States should be essentially a commercial and industrial state. Therefore, their agenda put great stress on the development of sea routes. It also included the acquisition of Florida and Louisiana, as well as an offer of assistance to Francisco de Mirenda, who was fighting for the independence of South America from Spanish supervision. In the Federalists' vision, the federal government should energetically protect American shipping interests with their expanding trade, which included the spice trade of the East Indies. They were determined to challenge Spanish and Portuguese sea powers and demanded that both make their ports available for American ships. ${ }^{20}$ Overall, as Dauer maintains,

Hamiltonian policy meant the abandonment of the neutrality and nonintervention policy advocated by Washington. It meant involvement in foreign adventure. At least a temporary alliance with England would have followed a declaration of war against France, and involvement in South America would probably have made this a more lasting one $[\ldots]$. What was projected was a complete change in the position that the United States had held since independence. ${ }^{21}$

\footnotetext{
"Inaugural Speech to Both Houses of Congress," in The Political Writings of John Adams, ed. George W. Carey (Washington, DC: Regnery Publishing, 2000).

${ }^{20}$ For detailed discussion of the Federalists' foreign policy agenda see Dauer, The Adams Federalists, 172-97.

${ }^{21}$ Ibid., 195-96.
} 
Significantly, the desire for war with France was in 1797 quite widespread among the commercial group of American citizens who sought ways to expand their commerce. The Federalists were also pushing for a war in order to discredit Jeffersonian Republicans (opposing the war) as disloyal and unpatriotic. ${ }^{22}$

Against this background, Adams' firm opposition to the Federalist agenda has to be interpreted in terms of the politics of disjunction. Not only was he determined to continue Washington's policy of neutrality, he also shared his predecessor's fear (inherited after English republicanism) of a large standing army, which would be necessary if America was to enter the war with France or Spain. ${ }^{23} \mathrm{He}$ wanted to maintain peace at all costs and suggested the development of navy - that is defensive forces. However, for peace with France (and peace was undoubtedly Adams' merit) the Federalists paid the price of a serious decomposition of their political camp, which in turn led to the lost elections in $1800 .{ }^{24}$ Moreover, the flow of history soon proved that Adams had tried to resist the inevitable. The purchases of Louisiana in 1803 and of Florida in 1819 clearly demonstrated that at the beginning of the nineteenth century, the American republic had already entered the era of quick territorial expansion.

Discrepancies between the second president of the United States and the Federalists were not limited to the foreign policy. As Dauer claims, there were crucial differences between them regarding fiscal and banking questions. ${ }^{25}$ Unlike Hamilton, Adams did not favor the wealthy class over others. He believed that banks, through certain financial operations, rob the community. It seems that his puritan mentality made him suspicious of emerging capitalism. "His strict moral code," writes Dauer, "caused him to condemn anything which smacked of speculation."26 He could not accept the idea of a profit disconnected from labor and based solely on interest. In his letter to John Taylor he describes "paper wealth" as "the madness of the many for the profit of a few." 27 His views on economic and fiscal issues were,

22 Ibid., 198-99.

${ }^{23}$ In his Farewell Address, Washington suggested to "avoid the necessity of those overgrown military establishments, which, under any form of government, are inauspicious to liberty, and which are to be regarded as particularly hostile to Republican Liberty." See George Washington, "The Farewell Address," in The Washington Papers, ed. Saul K. Padover (New York, NY: Harper and Brothers, 1955), 313. Adams' desire to maintain American neutrality was expressed already in his Inaugural Address, which could also be interpreted as a portent of continuation of his predecessor's policy in this regards. For more on that issue, see McCullough, John Adams, 469.

24 Grobis, Świat i polityka w pogladach, 16.

${ }^{25}$ Dauer, The Adams Federalists, 63-64.

${ }^{26}$ Ibid., 57.

27 John Adams, “To John Taylor, 14 April 1814," in The Works of John Adams, ed. Charles Francis Adams, Volume 6 (Boston: Little, Brown and Co., 1856), 508. 
obviously, an obstacle for the uninhibited growth of commercial groups. Instead he was in agreement with the agrarians, even when he opposed them on particular issues of political theory. Hamilton wanted to build a net of federal roads, increase the role of federal courts, develop federal bureaucracy and strengthen the Treasury Department. All this required raising taxes. Adams believed that those plans only supported the interests of one part of the country. He feared that realizing the Hamiltonian agenda would breakup the Union. Yet again, Adams' stance on this issue reveals his lack of readiness to adapt to changing times. He was, to some degree, an idealist believing in strict republican virtues (yet reinforced by puritan moderation). "To Adams," explains his biographer,

once a regime starts to face the future and begins to develop and modernize, there is little chance for the restoration of civic virtue and the classical return to first principles. "Will you tell me how to prevent riches from becoming the effects of temperance and industry?" Adams asked Jefferson as late as 1819. "Will you tell me how to prevent luxury from producing effeminacy intoxication extravagance Vice and folly?"28

Having studied the works of ancient writers, Adams saw the only chance for the lasting of any republic in the preservation of strict civic virtues. Although he admitted that people are self-interested and they must be encouraged to virtue, he was also afraid of any social and economic institution that might increase people's passions and desires. And once again, history brutally verified his ideals. Paradoxically, during Jefferson's administration the Hamiltonian economic agenda started to be consistently implemented. Once again, Adams' leadership proved to have all the traits of the politics of disjunction - aiming at the perpetuation of a regime and social structure which had already become outdated and no longer enjoyed general support.

Finally, Adams adopted quite literally Washington's warning against the development of the party system. He consequently presented himself as a "man of the whole nation" and distanced himself from party struggles. Already in his Inaugural Address he stressed that he was going to impartially represent the interests of the whole country and not just separate regions. ${ }^{29}$ Such an attitude (leaving aside Washington's influences) resulted largely from Adams' political theory. ${ }^{30}$

28 Diggins, John Adams, 167.

29 John Adams, "Inaugural Speech to Both Houses of Congress," in The Political Writings of John Adams, ed. George W. Carey (Washington, DC: Regnery Publishing, 2000), 639.

30 It should also be noted that the disdain for political parties and geographical divisions driven by interests was a steady element of Adams' thinking since his youth. See McCullough, John Adams, 397. 
He perceived the realm of politics in the terms of a class struggle between the poor and the rich. In order to achieve political stability, both groups should be represented in the legislature (hence Adams' stress on the superiority of bicameral over unicameral legislatures). Political representation, however, is not enough to prevent violent struggles that can potentially endanger the stability of society. What is necessary is a strong executive, acting as an arbiter and stabilizing the entire system. Adams' conception of presidency rested, to a great degree, on the foregoing vision of politics. "Equally skeptical of Jefferson's democracy as well as Hamilton's plutocracy," explains Diggins, "Adams looked to the executive to assure that government serves neither the many nor the few but the public good at large. Thus he entered the presidency assuming that if he conducted himself fairly, justly and independently, he would enjoy the respect and trust he deserved." 31

However, as Jerzy Grobis observes, Adams (perceiving himself as the continuator of Washington's policy) failed to notice substantial changes in the attitude of his contemporary politicians, who were more often ready to accept parties' interests rather than those of the president. ${ }^{32}$ Jefferson's victory in the 1800 elections proved that Adams' vision of an independent and impartial executive was, at the time, already a daydream. George Washington attempted to pursue such a policy by appointing people from all political factions for department heads in his administration, including both Jefferson and Hamilton. But before his second administration closed, this concept had already been abandoned out of necessity. By 1800 , progressing political polarization was making the presidential office more and more dependent on the support of one of two major political parties and according to Manning Dauer, this was precisely the reason why Washington refused to run for the third term. ${ }^{33}$ He understood very well that times had changed.

It seems that his successor had some difficulties with understanding that. Moreover, he did not take into account that even being the "Atlas of Independence" did not make him a "Cincinnatus of Mount Vernon."34 Adams, despite some

31 Diggins, John Adams, 13. Compare with Douglas Bradburn, "The Presidency of John Adams," in A Companion to John Adams and John Quincy Adams, ed. David Waldstreicher, Wiley-Blackwell Companions to American History (Malden, MA: Wiley-Blackwell, 2013), 167, 169, 171; and Greenstein, Inventing the Job, 32.

${ }^{32}$ Grobis, Świat i polityka w pogladach, 136.

33 Dauer, The Adams Federalists, 262.

34 Adams got the nickname of "Atlas of Independence" as a result of his devotion and extremely hard work during the First Continental Congress. He was one of the busiest delegates, participating in the works of more than 100 commissions and committees. See Grobis, Swiat i polityka w pogladach, 79. Also see Peter Shaw, The Character of John Adams (New York, NY: W. W. Norton, 1976), 76-105. "Cincinnatus of Mount Vernon" was, of course, a nickname of George Washington. 
signs of public respect, never enjoyed the enormous charisma that characterized Washington, whose very presence at the Constitutional Convention in Philadelphia was crucial for holding it together. In some of the southern states, where the position of anti-Federalists was very strong, the Constitution was ratified only because of a tacit understanding that the "father of the nation" would become the first president. With such a strong position and such prestige, Washington could relatively successfully pursue the policy of an independent, impartial president. What was possible in his case, however, could not succeed in the case of the lawyer from Braintree. As Dauer writes, Adams "still hoped throughout his administration, for the President to be regarded as above party, as representing the national interest" but "[ $t]$ he force which actually prevailed in the development of American politics was the growth of parties. The authority of the President rested upon political power as represented by these parties." 35

Also, the idea of a president as truly national leader - uniting all member-states of the Union, despite all the differences and partisan hostilities - became problematic even before Adams took that office. Nothing illustrates it better than the outcome of 1796 elections in which Massachusetts lawyer received only two electoral votes south of Mason-Dixon line. "There was no one to replace Washington as a national figure," observes Douglas Bradburn, "and the fantasy that the president could somehow stand above region - without an aggressive engagement in the nascent party system - should have been clear to Adams." 36 Should have been, but - as Adams' writings and letters attest - was not. Also in this regards, the second president of the United States lacked a precise insight into his times. While he "always prided himself on his independence," notices Bradburn, "his independence too often translated into isolation." 37

Adams' situation as a leader was all the more difficult because of problematic relationships with his own political camp. Throughout his presidency he felt Hamilton's presence behind his back. Members of his own cabinet often expressed greater loyalty to the New York politician than to their formal superior. By the end of his term, Adams' "grip on his office had become doubtful." 38 His determined decision to save peace with France in 1799 - contrary to Federalists' wishes - was the last attempt to regain control over his cabinet. He did not hesitate to purge it when its members conspired to scuttle his peace mission and preserve the party's war program. But that action took place too late. According to Skowronek,

35 Dauer, The Adams Federalists, 263.

36 Bradburn, "The Presidency of John Adams," 169.

37 Ibid.

38 Skowronek, The Politics Presidents Make, 67. 
Adams's final assertion of independence may have saved the nation from certain disaster, but it failed to save him from political disgrace. When push came to shove and Adams seized control in his own right, his own compatriots charged him with betrayal, and he went to the nation having repudiated the very system he seemed to represent. ${ }^{39}$

Perhaps most striking in the whole situation was the reaction of the main character in the story. According to Adams, "[t]he party committed suicide; they killed themselves and the national President [...] at one shot, and then as foolishly or maliciously indicated me for the murder." 40 The foregoing quote is a perfect illustration of both Adams' straightforwardness and his lack of readiness to practice party politics. Such a combination could not result - in the era of sharp crystallization of party divisions - in anything but a political failure.

\section{Selected Elements of Adams' Political Philosophy}

The style of his presidency and his vision of political leadership were not the only factors that distanced Adams from the majority of his contemporaries. His most fundamental philosophical views were quite unpopular as well. By defending them publicly (and stubbornly), the second president of the United States contributed all the more to practicing the politics of disjunction.

One of the best-known, and most often elaborated, elements of Adams' political philosophy was his appreciation of "natural aristocracy." Through historical studies he became convinced that every regime leads to the development of its own elite (or aristocracy). The "passion for distinction," as he wrote in Discourses on Davila, is one of the most profound feelings animating human behavior. ${ }^{41}$ Sooner or later, in any society, it will lead to the rise of social ranks and distinctions. More importantly, Adams perceived natural aristocrats as both useful and necessary "for all governments, even the most democratical, are supported by a subordination of offices, and ranks too. None ever existed without it but in a state of anarchy and outrage, in a contempt of law and justice, no better then no government." 42 Their existence, then, was not only natural but also beneficial for the political

\footnotetext{
${ }^{39}$ Ibid., 67-68.

40 John Adams, “To James Lloyd, 6 Feb. 1815," in The Works of John Adams, ed. Charles Francis Adams, Volume 10 (Boston: Little, Brown and Co., 1856), 115.

${ }^{41}$ John Adams, "Discourses on Davila," in The Political Writings of John Adams, ed. George W. Carey (Washington, DC: Regnery Publishing, 2000), 311.

42 John Adams, "A Defence of the Constitutions of Government of the United States of America," in The Political Writings of John Adams, ed. George W. Carey (Washington, DC: Regnery Publishing, 2000), 113.
} 
community. That is why Adams thought of philosophical doctrines appealing to universal equality as naive and annoying. "[W]hat are we to understand here by equality?" - he asked while commenting on Turgot's idea of government "founded on equality of all citizens."

Are the citizens to be all the same age, sex, size, strength, stature, activity, courage, hardiness, industry, patience, ingenuity, wealth, knowledge, fame, wit, temperance, constancy, and wisdom? Was there, or will there ever be, a nation, whose individuals were all equal, in natural and acquired qualities, in virtues, talents, and riches? The answer of all mankind must be in the negative. It must then be acknowledged, that in every state $[\ldots]$ there are inequalities which God and nature have planted there, and which no human legislator ever can eradicate. ${ }^{43}$

The foregoing words come from Adams' Defence of the Constitutions of the Government of the United States of America and had been published less than two years before he became vice-president. Nothing illustrates better the disjunction between Adams' philosophical views and progressing leveling trends than a comparison with the opening of the famous Democracy in America written by Tocqueville forty years later, in which he characterized American society of that time in the following way:

Amongst the novel objects that attracted my attention during my stay in the United States, nothing struck me more forcibly than the general equality of conditions. [...] The more I advanced in the study of American society, the more I perceived that the equality of conditions is the fundamental fact from which all others seem to be derived, and the central point at which all my observations constantly terminated. ${ }^{44}$

Forty years after the publication of Adams' work, the dominant feeling among Americans was already "passion for equality." 45 But obviously, egalitarian trends started much earlier and intellectuals' sympathies for democratic ideals of the French Revolution were already strong in the times of Adams' leadership. Against their background, his writings had to be perceived by a substantial part of the general public as conservative, or even reactionary. Similarly, his campaign for establishing certain titles for the highest officials and ceremonies modeled on

\footnotetext{
${ }^{43}$ Ibid., 141-42. Also see ibid., 148.

${ }^{44}$ Alexis de Tocqueville, Democracy in America, ed. Bruce Fronhen, transl. Henry Reeve (Washington, DC: Regnery Publishing, 2002), 3.

45 Ibid., 463.
} 
the patterns of European etiquette contributed greatly to solidifying his image as a "concealed monarchist." Adams' motives (as his letters prove) were honest and based on the desire to increase the authority and prestige of the young republic's president on the international arena. But those efforts - undertaken in times of the quick dissemination of progressive democratic and egalitarian ideals of the French revolution - were completely wrongly perceived. ${ }^{46}$ While French revolutionists were abolishing all titles and distinctions (treated as anachronisms of the feudal era), Adams tried to persuade Congress to adopt the title "Majesty" for Washington. Republican press and Adams' political opponents reacted with violent attacks. He was accused not only of monarchical sympathies but also of betraying liberty and republican ideals. According to his critics, " $\mathrm{t}] \mathrm{he}$ pseudo-president, the 'Duke of Braintree,' was planning to marry one of his sons to the daughter of George III, and thus America would awake one day to discover it had an inherited monarchy and had been reunited with England." 47 Anyone who knew Adams' true political views could tell that those accusations were unfair. In his letter from October 18, 1790, to Samuel Adams, he assured: "It is a fixed principle with me, that all good government is and must be republican." 48 Nevertheless, the monarchist label clung to Adams and his chances for explaining the subtle complexity of his political convictions, as well as for correcting all misunderstandings, were close to none.

The foregoing remarks must be considered in the broader intellectual and political climate dominating in America at the time. Thomas Paine's pamphlet The Rights of Man - a direct polemic with Burke's Reflections on the Revolution in France - was welcomed by progressive American thinkers and politicians with a common enthusiasm. Such a political climate surely was not conducive to formulation of the theories of natural aristocracy. Democratic social ideas propagated by Thomas Jefferson were gaining greater and greater recognition at the beginning of the nineteenth century. In this context, the political writings of vice-president

${ }^{46}$ As Joyce Appleby noticed, Adams' attempt to establish elaborate titles for Washington were probably influenced by his fascination with political theory of Jean Louis De Lolme. However, in this particular case "De Lolme proved to be a siren song for Adams, pulling him away from his grasp of American sensibilities." See Joyce Appleby, "The New Republican Synthesis and the Changing Political Ideas of John Adams," American Quarterly 25, no. 5 (1973): 589.

47 Diggins, John Adams, 161. Also see Grobis, Świat i polityka w pogladach, 124-25, 131, 142. Parrington writes extensively on how the unfortunate moment of publication of Adams' philosophical works discussing the problem of natural inequality and aristocracy coincided with his political efforts aiming at introduction of the titles for high officials. See Parrington, Main Currents in American Thought, 311.

48 John Adams, "To Samuel Adams, 18 October 1790," in The Political Writings of John Adams, ed. George W. Carey (Washington, DC: Regnery Publishing, 2000), 665. 
Adams were damaging both to him and to the Federalist camp. His Discourses on Davila, originally published as separate letters in The Gazette of the United States, only deepened the author's political isolation. ${ }^{49}$ Ruthlessly attacked by the Left, he was simultaneously regarded as too straightforward by the republican, more conservatively oriented Right. In response to the critique, Adams consistently tried to present himself as a "man of the whole nation," but this strategy - as explained earlier - was no longer viable. The French Revolution marked the beginnings of modern democracy as well as modern political parties (also in America), and Adams was too uncompromising thinker to change his views only because of their unpopularity.

The second president of the United States looked with a great concern at the revolutionary turmoil in France. He was afraid of the revolution, which he identified with the state of lawlessness and the decay of society. The French events did not remind him of the American severance of ties with Britain originating in 1776. Diggins, summarizing his fears, wrote:

Against the crusading revolutionary exuberance of Jefferson and Tom Paine, who also believed that heads must fall so that freedom may arise, Adams sought to keep things in perspective. "Our was a revolution against innovation," he emphasized, reminding Americans that the "spirit of " 76 " was meant to preserve old freedoms, not to propagate new fictions. ${ }^{50}$

For Adams, the art of restraining men's passions and desires, through wise and well-designed institutions, was the peak of political science. The French Revolution was, from this perspective, a great misunderstanding. Instead of reducing emotions and passions, it kindled them. Moreover, it resulted in the introduction of a democratic form of government - the one which is the most conducive to people's passions and devoid of checks and balances. In democracy - the regime that gives direct and ultimate power to the people - passions reach their critical level. That is why, in Adams' opinion, democracy means a state of permanent disorder and easily transforms into anarchy. He noticed in "pure democracy" exactly the same disadvantages that had already been identified by Plato. In such

49 Their publication was suspended after the 37th letter because of the overwhelming negative public reaction. See Grobis, Świat i polityka w poglądach, 129, 131.

${ }^{50}$ Diggins, John Adams, 7-8. For a summary of Adams' views on the French Revolution see Zoltán Haraszti, John Adams \& the Prophets of Progress (New York, NY: Grosset and Dunlap, 1964), 180-234; and Edward Handler, America and Europe in the Political Thought of John Adams (Cambridge, MA: Harvard University Press, 1964), 156-90. 
a regime, a class struggle between the rich and the poor is inevitable. The latter will, at a certain moment, desire to take property from the former: debts will be annulled, heavy taxes laid on the rich and, ultimately, equal distribution of wealth will be enforced. Private property was for Adams a sacred right, which is why he perceived democracy as a threat to human freedom. The people, contrary to what was said by French philosophées, is not the best guardian of its liberties. In fact, it is the worst one. "Adams said in 1788 what Lincoln said in 1838: The Constitution is necessary to protect people from their worst enemy - themselves." ${ }^{11} \mathrm{He}$ was convinced that democracy, which is not based on the rule of law - but rather on human passions - never lasts long. In a short time it exhausts itself and commits suicide. ${ }^{52}$ Needless to say, such views did not win him sympathy in the democratizing political environment of America at the beginning of the nineteenth century.

Adams looked for the remedy against excesses of pure democracy in the old, tested British constitution. He consequently defended not only the idea of a mixed government but also the notion of an "aristocratic republic" - based on the qualification, education and wisdom rather than changeable, unpredictable, irrational passions of the people. In the debate between Anglomanes and Jacobins Adams took part of the former. ${ }^{53}$ However, while his views - expressed in the Defence of the Constitutions of Government of the United States of America - were rooted soundly in the context of contemporary European discussions, they were at the same time more and more "anomalous" on American soil. As Gordon Woods observes, Adams' political and constitutional theory was simply "contrary to the central thrust of [American] constitutional thought in 1787." 54

It is noteworthy that Adams perceived human nature in universal terms. Therefore, he refused to treat American experiment in government as something exceptional. He was convinced that the same laws which apply to all societies and political phenomena bound also his fellow citizens. American political and social institutions were exposed to the same passions and dangers that were well documented and analyzed by historians and political thinkers; hence his devotion

\footnotetext{
${ }^{51}$ Diggins, John Adams, 172.

${ }^{52}$ For Adams' views on democracy see Stanisław Filipowicz, O władzy grzechu i grzechach władzy. Rozważania o rodowodzie amerykańskiego antyutopizmu [On the power of sin and the sins of power. Reflections on the genealogy of American anti-utopianism] (Warszawa: Oficyna Naukowa, 1992), 216-18. Also see Parrington, Main Currents of American Thought, 313-16; Dauer, The Adams Federalists, 42, 50, 53; Diggins, John Adams, 6-8, 172; and Grobis, Świat i polityka w pogladach, 112.

${ }^{53}$ For more on this subject see Appleby, "The New Republican Synthesis."

54 Gordon S. Wood, The Creation of the American Republic, 1776-1787 (Chapel Hill, NC: University of North Carolina Press, 1968), 580.
} 
to studying history. ${ }^{55}$ This scholastic disposition influenced his understanding of politics as well as the vision of his own presidency. One might argue that being so deeply rooted in universal historical studies at times made Adams a poor reader of his own times and specifically American needs and expectations.

\section{Conclusion}

The foregoing considerations seem to confirm the thesis that John Adams is an example of a political leader pursuing the politics of disjunction. He undertook the great effort of sustaining the classical republican understanding of politics and political institutions in an era of progressive democratization. Both his philosophical views and political decisions made as the head of the executive branch went against the tide. In an era of democratization and progressing egalitarianism he praised the positive role of aristocracy and social hierarchy. While the progressive world marveled at the achievements of the French Revolution, he praised British republicanism as the greatest form of government that had ever existed.

The question that needs to be addressed at this point is whether Adams was simply a poor observer of his immediate political surroundings or if he consciously refused to conform to them. Many arguments support the latter answer. According to Parrington, Adams never bowed to the mood of the crowd and never cared for popularity when expressing his views. ${ }^{56} \mathrm{He}$ always spoke from the principle he believed was right. He surely was, as Diggins aptly described him, a "moralist in politics":

Adams was a case of Niebuhr's "moral man in immoral society," a president who believed in honor and upheld ideals that, curiously enough, his own modernist theory of the "machinery of government" did not require. Convinced that human nature is inevitably egoistic and prone to sin, he believed that the president cannot count upon ideals as motives of action. Thus, the very virtues he asked of himself he doubted he would find in the people themselves. ${ }^{57}$

\footnotetext{
${ }^{55}$ Kurtz, "The Political Science," 610, 612-13. Adams devotion to studying politics resulted in a great erudition on one hand but also in the imitative nature of his own political thought. Zoltán Haraszti claims that at least three-fourths of Adams' two major works - Defence of the Constitutions and Discourses on Davila - are direct quotations from other authors like Adams Smith or Machiavelli. See Haraszti, John Adams \& the Prophets of Progress, 46-47.

56 Parrington, Main Currents of American Thought, 308.

57 Diggins, John Adams, 173.
} 
In the light of the foregoing quote, Adams' leadership suits a category of the politics of disjunction. Impressive historical and philosophical studies resulted in the conviction that the young American republic needed the perpetuation of already tested principles of British constitutionalism, supplemented by the mechanism of checks and balances as well as the existence of an enlightened, noble leadership. He advocated public policies and believed in philosophical ideals that were unacceptable for many of his contemporaries. He himself was probably quite aware of that fact. Several weeks after the presidential inauguration, he spoke of his isolation in almost every letter to his wife. ${ }^{58}$ With time, frustration and bitterness grew in him, but could events have transpired differently? "Combine Adams' philosophical reflections with his political aspirations, and what do we get?" - asks his biographer. "A formula for frustration. While he doubted that the people had a capacity to think rationally and to act virtuously, he would see himself as doing so, only to wonder why he went unappreciated in a democracy of the unenlightened." ${ }^{59} \mathrm{He}$ was a tragic figure, whose conservative social policy was not accepted among his contemporaries. His leadership is an example of the failure of the "man of principles" in the realm of politics.

\section{Biographical Note}

Dr. Marcin Gajek is associate professor at the Institute of Sociology at Collegium Civitas in Warsaw. His research interests include political philosophy and history of political thought. E-mail: marcin.gajek@civitas.edu.pl

\footnotetext{
58 Dauer, The Adams Federalists, 120.

59 Diggins, John Adams, 11.
} 